\title{
SHORT-TERM IMPACTS OF COVID-19 PRECAUTIONS ON UNEMPLOYMENT IN NUTS-3 REGIONS OF TURKEY
}

\author{
Barış ERGEN ${ }^{a}$
}

\begin{abstract}
This study examines the short-term effects of the COVID-19 pandemic on unemployment in Turkey. The data used in this study are from monthly insured bulletins of the Social Security Institution (SSI) of Turkey. The number of active insured employees in NUTS-3 regions of Turkey was analyzed in three periods: (1) in December 2019, when the first official case of COVID-19 was announced in the world, (2) in March 2020, when the first official case of COVID-19 was reported in Turkey, and (3) at the end of May 2020, when the normalization period was declared in Turkey. Both increases and decreases in employment in these three periods were examined in percentage. This study finds that employment increased by 9.024 from December 2019 to March 2020. However, the number of active insured employees decreased by 657,417 from March to May 2020 due to the pandemic measures implemented after the first case of COVID-19 was detected in Turkey. After the normalization period was declared in May 2020, the number of active insured employees increased by 529,249 within one month. This illustrates the negative effects of the COVID-19 measures on employment. Metropolitan cities are more affected by the COVID-19 pandemic due to their different sectorial structures, their significant economic relations with other cities and the world, and the more stringent COVID-19 measures in these cities than other provinces by covering weekends, which led to higher unemployment in metropolitan cities. Another important result of this study is that the COVID-19 measures had negative effects on employment in urban economies, and if these short-term effects continue in the long term, the negative effects will be greater in urban economies. Therefore, this study concludes that urban economies cannot sustain these COVID-19 measures any longer.
\end{abstract}

Keywords: Urban economy, COVID-19, unemployment, NUTS-3, Turkey

$$
\text { 䊏 }
$$

\section{TÜRKIYYE'NINN İBBS-3 BÖLGELERINNDE COVID-19 ÖNLEMLERINIIN İŞSIZLLIKK ÜZERINDE KISA VADELİ ETKİLERİ Özet}

Türkiye' de COVID-19'un işsizliğe kısa dönemli etkisini araştırmayı amaçlayan bu çalışmada Sosyal Güvenlik Kurumu'nun aylık sigortalı bülteninde yer alan veriler kullanılmıştır. Aktif çalışan sigortalı sayıları üç

a Prof. Dr. Erciyes Üniversitesi, Mimarlık Fakültesi, Şehir ve Bölge Planlama, ergen@erciyes.edu.tr Makale Geliş Tarihi: 14.06.2021, Makale Kabul Tarihi: 28.08.2021 
dönemde incelenmiştir. Birinci dönem Dünya' da ilk resmi COVID-19 vakasının açıklandığı 2019 Aralık ayıdır. İkinci dönem Türkiye' de ilk resmi vakanın açıklandığı Mart 2020'dir. Üçüncü dönem normalleşme döneminin açıklandığı 2020 yılı Mayıs ayıdır. Bu üç dönemde istihdamdaki yüzde olarak artış ve azalışlar oransal incelenmiştir. Dünyada ilk vakanın tespit edildiği Aralık 2019 ile Türkiye'de ilk vakanın tespit edildiği Mart 2020 arasında istihdamda 9024 kişi artış olduğu görülmüştür. Türkiye'de ilk vaka tespitinden sonra uygulanan tedbirler sonucunda Mart 2020 ve Mayıs 2020 dönemi arasında sigortalı çalışan sayısında 657.417 azalma olduğu tespit edilmiştir. 1 Haziran ile birlikte normalleşme kararları sonrasında tedbirlerin uygulandığı 2020 Mayıs verilerine göre aktif sigortalı çalışan sayısında bir ay içinde 529.249 kişi artış yaşanmıştır. Kısıtlamaların kaldırılması ile istihdamda artış olması, COVID-19 tedbirleri kapsamında alınan tedbirlerin istihdama olumsuz etkisinin olduğu birinci varılan sonuçtur. Büyükşehir statüsündeki illerin farklı sektörel yapısı, dünya ve diğer kentlerle olan ekonomik ilişkileri nedeniyle kısıtlamalardan daha fazla etkilenmiştir. Tedbirlerin büyükşehirlerde hafta sonunu kapsayacak şekilde diğer illere göre daha sıkı uygulanması büyükşehirlerde daha fazla işsizliğe neden olduğu çalışmanın diğer önemli sonucudur. COVID-19'u önlemeye yönelik tedbirlerin kent ekonomilerine istihdam yönünde olumsuz etkilerinin olduğu, kısa dönemli bu etkilerin uzun dönemli olarak sürmesi durumunda kent ekonomilerinde olumsuz etkilerin çok daha fazla hissedileceği çalışmanın bir başka önemli sonucudur. Kent ekonomilerinin bu süreci daha fazla sürdüremeyeceği çalışmanın vardığg diğer bir önemli sonuçtur.

Anahtar Kelimeler: Kentsel ekonomi, COVID-19, işsizlik, NUTS-3, Türkiye

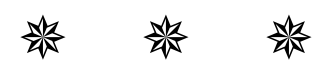

\section{Introduction}

Many factors affect the urban economy. Urban economy is affected by sectoral structure, transformation of the sectoral structure, employment, labor and workforce relations, the changes in land values and rents in the cities, and their effects on investments, production and consumption relations, trade, economic relations and globalization. The dynamic structure of cities has been further enhanced by global relations. Negative effects in urban economy occur decrease in the attractiveness of the city. Any impact on the dynamic structure of cities affect the urban economy.

Cities are born to be dynamic. They are growing, changing, decaying, and redeveloping. Most people prefer urban life for its dynamic feelings, activities, and opportunities, which are not present in rural life. A city will lose its meaning and attractiveness when it becomes stagnant and motionless (Miyao 1981, p:1).

By referring to Jacobs (1969), Polèse (2005) emphasized that cities are the primary organ of an economy. Polèse (2013) stated that dramatic changes in cities are mostly due to external effects and technological changes, and he highlighted that cities with strong accessibility and good connections with the world grow more than other cities. Therefore, the interconnection of cities plays a very important role in their economies. Interruptions in economic relations and mobility of cities will have negative effects on them. Urban economy has many different components, and employment is one of the components that is negatively affected by external factors, such as the COVID-19 pandemic.

Measures to prevent epidemics, such as curfews, prohibition of travel between provinces and countries, slowing down production, flexible and home-working models, and restriction or prohibition of non-compulsory urban activities reduce urban movement and inhibit urban life. Stagnation of urban 
life has negative effects on urban economic activities, which vitalize the city. Unemployment is one of these negative effects. Suarez-Villa (1998) emphasized that although urban problems reflect the processes of sectorial change, rather than isolated effects, they affect not only metropolitan areas but also the whole urban system irreversibly. Thus, isolation practices to prevent epidemics and "stay at home" calls create irreversible effects on urban economies. Regarding sectorial changes, it affects not only certain cities but also the entire urban system. Batty (2020) stated that the COVID-19 pandemic will dramatically affect globalization. Before the pandemic, national and urban economies were interconnected due to globalization, but the pandemic has adversely affected this interconnection.

COVID-19 first appeared in Wuhan, China in December 2019 and soon turned into a pandemicspreading all over the world. The first official case of COVID-19 in Turkey was reported on March 11, 2020. From that date, several measures have been taken in many different sectors, such as education, sports activities, cafes, restaurants, and entertainment sectors to prevent the spread of the pandemic, and several restrictions have been imposed on domestic and international transportation and travel. Unlike other provinces, curfews were declared in NUTS-3 regions, which have gained the status of metropolitan municipality, on weekends. Tekeli (2020) argued that there are two important stages of the COVID-19 pandemic, which are (1) prohibiting domestic displacements and large social activities to significantly reduce human contact in order to pass through the most severe period of the crisis, and (2) making the necessary decisions for the transition to the new normal after the crisis (Tekeli, 2020). The measures taken to prevent the spread of the virus has had negative effects on the economy. The COVID-19 pandemic has brought global markets to a standstill, causing the biggest economic crisis after the 1929 Great Depression, where financial markets suffered a great loss (Göze Kaya, 2020). Globalization has three dimensions, economic, cultural and political (Kalu \& Ogbonnaya, 2019). Economic globalization focuses on the liberalization of production, investment and trade, technological developments and labor mobility (Babones, 2007; Schneider, 2007). Turkey's articulation to the global economy and the adoption of neoliberal policies began to increasingly affect cities after the decisions of January 24, 1980 (Güzey, 2012; Öktem 2011). The global urban discourse noted by Öktem (2006) and emphasized by Friedmann and Wolff $(1982)$ and later by Sassen $(1991,1994)$ has resulted in cities increasingly taking a greater role in the world economy. Along with economic globalization, the liberalization of production, investment and trade also had a significant impact on the labor force of cities. In this global relations, cities of Turkey has been adversely affected by COVID-19 precautions.

Bonaccorsi et al. (2020) examined the effects of COVID-19 measures on the Italian economy and stated that economic closure and quarantine disproportionately affect weak companies in both production and service sectors. The OECD estimated that a quarterly economic closure will reduce gross domestic product by 4 to 6 percent (Beirne et al., 2020).

| 1118 | These negative effects on the economy due to the COVID-19 pandemic have also negatively affected the labor market. In particular, restrictions on human mobility, closure of country borders, curfews, restrictions on the entertainment sector, and measures to prevent people from coming together have caused employees in many different sectors to lose their jobs. How will the "transition to the new 
normal," a concept introduced by Tekeli (2020), decreased social opportunities and thus attractiveness of cities and reduced urban mobility change the structure of cities?

As can be seen from the literature study, the restriction of urban economies connected by the influence of globalization due to COVID-19 is expected to have negative effects on the economy. But it is certain that there is also a need for evidential work on how it affects or will affect the workforce. The idea of investigating how restrictions and precautions affect the direction of employment led to the study.

\section{A. DEFINITION OF THE PROBLEM, SCOPE, AND METHOD}

There are 81 NUTS-3 regions in Turkey. NUTS-3 regions are provincial regions. In this study, the main research question is "How has the COVID-19 pandemic affected labor in NUTS-3 regions of Turkey in the short term?" This study examines three periods: (1) December 2019, when the first official case of COVID-19 was announced in the world, (2) March 2020, when the first official case of COVID-19 was reported in Turkey, and (3) the end of May 2020, when the normalization period was declared in Turkey. This study examines the economic impact of short-term measures on employment in NUTS-3 regions. These measures were taken from December 2019, when there was no COVID-19 case and related measures in Turkey, to March 11, 2020, when the first COVID-19 case was reported and relevant measures were implemented in Turkey, and the beginning of June 2020, when the normalization process was initiated in Turkey. This study uses monthly unemployment data of NUTS-3 regions of Turkey, which are derived from the SSI's monthly insured employee data. Workers data in the active insured employee data are the basis of this study. Since the jobs of civil servants are guaranteed, their data were not included in this study. To determine the impact of the COVID-19 measures on unemployment, this study examines the data on the number of active insured employees in December 2019, March 2020, and May 2020 when no COVID-19 measures had been implemented in the NUTS-3 regions of Turkey, when the first COVID-19 case was reported and relevant measures were taken in Turkey, and when the COVID-19 measures were implemented, respectively. The rate of change in the workforce is measured from December 2019 to May 2020. To understand the impact of the COVID-19 measures on unemployment, the number of active insured employees in March 2020 is compared with those in December 2019 and May 2020. Since this study includes monthly active insured employee data, the data of 2016, 2017, 2018, and 2019 are used to determine the effect of the measures taken to prevent the spread of COVID-19 on unemployment. NUTS-3 regions with a 1\% change in unemployment rate were grouped; this rate is used as the benchmark in this study. NUTS-3 regions with an unemployment rate of more than 5 percent are considered the most fragile regions. The change in the workforce due to the measures implemented in March, April, and May 2020 was examined under six groups, which are NUTS-3 regions with an increased workforce, NUTS-3 regions where the number of active insured employees decreased by 0 to 1 percent, 1 to 2 percent, 3 to 4 percent, 4 to 5 percent, and more than 5 percent.

\section{B. RESULTS}

The data of active insured employees before the COVID-19 pandemic, including those from 2016 to 2020, were examined to determine the effect of the COVID-19 pandemic on unemployment. As shown in Table 1, the number of active insured employees was relatively stable from 2017 to the beginning of 
2020. It decreased by 2.2 percent from 2017 to the end of 2019. The number of active insured employees was 16,019,026 in March 2020. However, it dropped to 15,361,609 in May 2020, following the implementation of government measures, including curfews, "stay safe and stay home" calls, and travel restrictions to prevent the spread of COVID-19 after the first case was reported in Turkey in March 2020. As a result of these measures implemented in April and May 2020, the number of active insured employees decreased by 4.2 percent; the number of active insured employees was less than that of 2016. After lifting governmental bans following the normalization decision taken on June 1, 2020, the number of active insured employees increased by 529,249 and reached 15,890,858. Thus, the measures had a significant effect on unemployment in Turkey.

Table 1. Number of active insured employees (2016-2020 June)

\begin{tabular}{lccccccc}
\hline Year & 2016 & 2017 & 2018 & 2019 & March 2020 & May 2020 & June 2020 \\
\hline Active insured employees & $15,355,158$ & $16,369,073$ & $16,054,759$ & $16,010,002$ & $16,019,026$ & $15,361,609$ & $15,890,858$
\end{tabular}

Source: Social Security Institution [SSI]. (2020, August, 31) Monthly Insured Statistics Bulletin

Examining the distribution of 2019, March 2020, and May 2020 data about NUTS-3 regions (Table 1 ) is important in determining the effect of the COVID-19 measures on provinces. At this stage of the study, the data on NUTS-3 regions are evaluated. The impact of the COVID-19 pandemic was different in each NUTS-3 region. It had no negative effect on unemployment in some NUTS-3 regions but caused serious unemployment problems in other NUTS-3 regions. The short-term negative effects of the COVID19 pandemic on unemployment are not observed in some NUTS-3 regions, including Rize, Bitlis, Kars, Çorum, Erzincan, Elazı $\breve{g}$, Tunceli, Erzurum, and Batman. As Table 2 shows, some NUTS-3 regions experienced an increase in employment; the highest increase was in Rize and the least increase was in Batman. Among these NUTS-3 regions, only Erzurum is a metropolitan municipality, which is marked in gray in Table 2.

Table 2. NUTS-3 regions with an increase in employment from December 2019 to May 2020

\begin{tabular}{lllll}
\hline & December 2019 & March 2020 & May 2020 & $\begin{array}{l}\text { Change \% } \\
\text { (from December 2019 to May 2020) }\end{array}$ \\
\hline Rize & 58,219 & 58,742 & 63,603 & 9.25 \\
\hline Bitlis & 32,038 & 31,911 & 33,966 & 6.02 \\
\hline Kars & 26,047 & 25,703 & 27,005 & 3.68 \\
\hline Çorum & 69,439 & 70,160 & 70,520 & 1.56 \\
\hline Erzincan & 32,382 & 32,034 & 32,779 & 1.23 \\
\hline Elazĭg & 77,046 & 74,729 & 77,937 & 1.16 \\
\hline Tunceli & 9,305 & 8,935 & 9,403 & 1.05 \\
\hline Erzurum & 88,853 & 88,588 & 89,251 & 0.45 \\
\hline Batman & 78,128 & 79,249 & 78,420 & 0.37 \\
\hline
\end{tabular}

Source: Social Security Institution [SSI]. (2020, August, 31) Monthly Insured Statistics Bulletin

| 1120 | As depicted in Figure 1, NUTS-3 regions with an increase in employment are mainly located in the east and northeast of Turkey. In the provinces where the negative effects of COVID-19 on employment were not experienced from December 2019 to May 2020, the employment rate increased by $6.02 \%$ in Bitlis, $3.68 \%$ in Kars, $1.56 \%$ in Çorum, 1.23\% in Erzincan, 1.16\% in Elazı $\breve{g}$, and 1.05\% in Tunceli. 


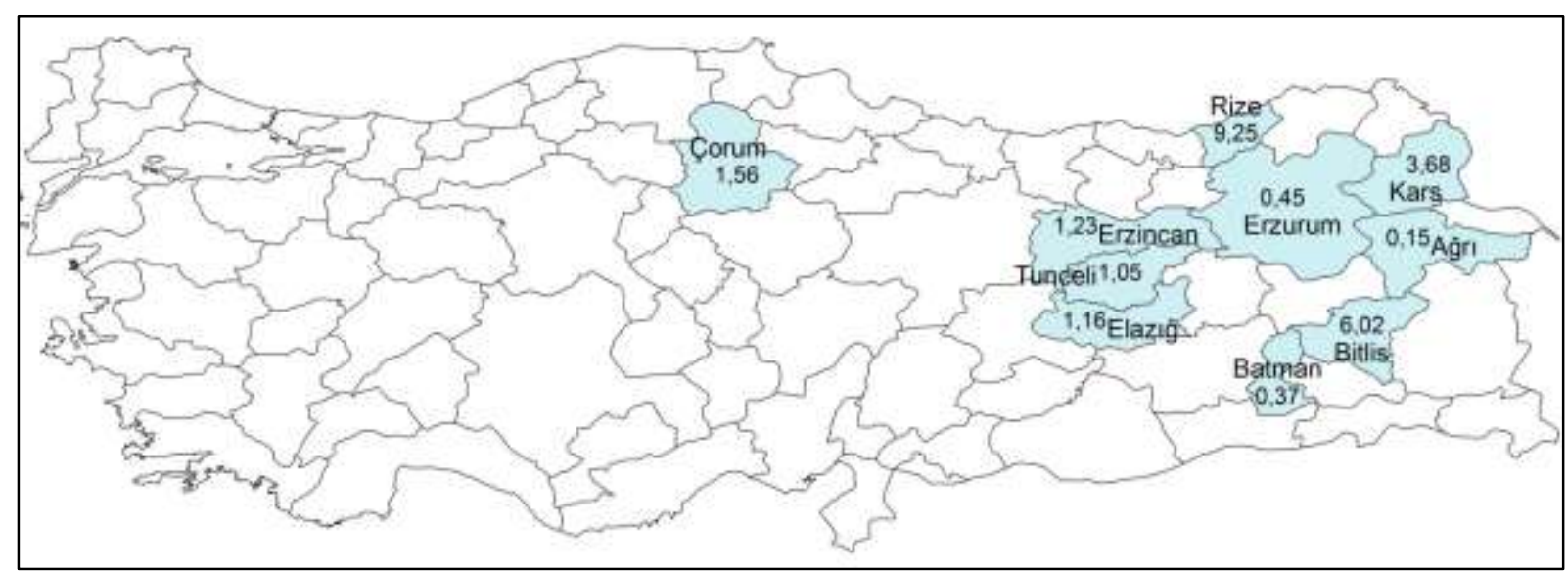

Figure 1. NUTS-3 regions with a decrease in unemployment from December 2019 to May 2020

Table 3 shows NUTS-3 regions where the change in the number of active insured employees from December 2019 to May 2020 varies negative percent. The NUTS-3 regions of metropolitan municipalities are shown in gray in Table 3. Increasing employment from December 2019 to March 2020 (before the COVID-19 measures were implemented) has been shown as bold in column.

Table 3. NUTS-3 regions with decrease in employment from December 2019 to May 2020

\begin{tabular}{|c|c|c|c|c|}
\hline & December 2019 & March 2020 & May 2020 & $\begin{array}{l}\text { Change \% } \\
\text { (December } 2019 \text { - May 2020) }\end{array}$ \\
\hline Aksaray & 57,881 & 58,289 & 57,767 & -0.20 \\
\hline Muş & 34,702 & 33,717 & 34,510 & -0.55 \\
\hline Iğdır & 18,775 & 18,417 & 18,670 & -0.56 \\
\hline Mardin & 93,192 & 93,541 & 92,474 & -0.77 \\
\hline Muğla & 202,050 & 210,768 & 200,482 & -0.78 \\
\hline Nevşehir & 49,630 & 50,454 & 49,112 & -1.04 \\
\hline Balıkesir & 196,151 & 198,544 & 194,001 & -1.10 \\
\hline Gaziantep & 332,406 & 335,975 & 327,868 & -1.37 \\
\hline Bingöl & 29,362 & 29,350 & 28,932 & -1.46 \\
\hline Sinop & 27,957 & 27,757 & 27,524 & -1.55 \\
\hline Kocaeli & 539,606 & 545,180 & 531,236 & -1.55 \\
\hline Kastamonu & 54,366 & 54,076 & 53,425 & -1.73 \\
\hline Tekirdağ & 285,775 & 289,132 & 280,570 & -1.82 \\
\hline Çanakkale & 95,576 & 96,013 & 93,804 & -1.85 \\
\hline Çankırı & 28,579 & 28,339 & 28,023 & -1.95 \\
\hline Diyarbakır & 175,265 & 174,816 & 171,781 & -1.99 \\
\hline Karaman & 43,717 & 43,523 & 42,826 & -2.04 \\
\hline Hakkari & 28,889 & 26,709 & 28,250 & -2.21 \\
\hline Hatay & 200,956 & 201,704 & 196,436 & -2.25 \\
\hline Tokat & 69,365 & 69,167 & 67,734 & -2.35 \\
\hline Artvin & 29,180 & 28,455 & 28,490 & -2.36 \\
\hline Adıyaman & 67,352 & 66,633 & 65,737 & -2.40 \\
\hline Şanlıurfa & 168,535 & 166,575 & 164,475 & -2.41 \\
\hline Malatya & 118,636 & 115,143 & 115,714 & -2.46 \\
\hline Ordu & 101,064 & 100,445 & 98,517 & -2.52 \\
\hline Kahramanmaraş & 165,304 & 164,447 & 161,084 & -2.55 \\
\hline
\end{tabular}


Barıș ERGEN

\begin{tabular}{|c|c|c|c|c|}
\hline Van & 108,638 & 106,064 & 105,864 & -2.55 \\
\hline Zonguldak & 99,363 & 99,421 & 96,812 & -2.57 \\
\hline Mersin & 287,622 & 287,312 & 280,160 & -2.59 \\
\hline Osmaniye & 61,577 & 61,639 & 59,968 & -2.61 \\
\hline Kirıkkale & 38,952 & 38,842 & 37,862 & -2.80 \\
\hline Yozgat & 47,311 & 45,659 & 45,986 & -2.80 \\
\hline Edirne & 66,348 & 67,481 & 64,430 & -2.89 \\
\hline Kütahya & 93,769 & 92,855 & 90,970 & -2.98 \\
\hline Afyonkarahisar & 105,538 & 104,491 & 102,309 & -3.06 \\
\hline Bolu & 64,268 & 64,221 & 62,287 & -3.08 \\
\hline Kayseri & 244,362 & 243,695 & 236,637 & -3.16 \\
\hline Düzce & 78,290 & 79,210 & 75,645 & -3.38 \\
\hline Konya & 348,988 & 345,705 & 337,161 & -3.39 \\
\hline Kırşehir & 29,110 & 29,289 & 28,104 & -3.46 \\
\hline Aydın & 168,440 & 168,934 & 162,535 & -3.51 \\
\hline Ardahan & 10,467 & 10,147 & 10,097 & -3.53 \\
\hline Amasya & 46,671 & 46,467 & 45,017 & -3.54 \\
\hline Samsun & 192,106 & 191,435 & 185,225 & -3.58 \\
\hline Manisa & 271,778 & 271,739 & 261,552 & -3.76 \\
\hline Bursa & 740,274 & 736,445 & 711,868 & -3.84 \\
\hline İzmir & 966,665 & 966,829 & 929,459 & -3.85 \\
\hline Bartın & 32,152 & 32,432 & 30,828 & -4.12 \\
\hline Sakarya & 205,278 & 206,569 & 196,710 & -4.17 \\
\hline Siirt & 34,999 & 33,824 & 33,485 & -4.33 \\
\hline Şırnak & 55,824 & 54,415 & 53,364 & -4.41 \\
\hline Antalya & 539,731 & 550,023 & 515,192 & -4.55 \\
\hline Bayburt & 9,830 & 9,617 & 9,379 & -4.59 \\
\hline Denizli & 213,868 & 212,135 & 203,966 & -4.63 \\
\hline Giresun & 65,558 & 65,621 & 62,429 & -4.77 \\
\hline Adana & 348,733 & 340,285 & 331,854 & -4.84 \\
\hline Kırklareli & 74,088 & 73,715 & 70,491 & -4.86 \\
\hline Trabzon & 133,452 & 130,176 & 126,819 & -4.97 \\
\hline Uşak & 72,185 & 72,191 & 68,445 & -5.18 \\
\hline İstanbul & $4,425,287$ & $4,454,430$ & $4,185,517$ & -5.42 \\
\hline Bilecik & 50,236 & 49,326 & 47,483 & -5.48 \\
\hline Yalova & 65,405 & 65,588 & 61,687 & -5.68 \\
\hline Eskişehir & 185,525 & 183,481 & 174,805 & -5.78 \\
\hline Sivas & 84,176 & 81,161 & 79,273 & -5.82 \\
\hline Gümüşhane & 17,136 & 16,812 & 16,101 & -6.04 \\
\hline Ankara & $1,386,780$ & $1,381,655$ & $1,287,223$ & -7.18 \\
\hline Kilis & 19,473 & 19,217 & 17,908 & -8.04 \\
\hline Karabük & 42,084 & 41,465 & 38,637 & -8.19 \\
\hline Isparta & 73,255 & 72,717 & 67,194 & -8.27 \\
\hline Niğde & 43,913 & 42,787 & 39,827 & -9.30 \\
\hline Burdur & 39,299 & 39,019 & 35,196 & -10.44 \\
\hline
\end{tabular}

Source: Social Security Institution [SSI]. (2020, August, 31) Monthly Insured Statistics Bulletin

As depicted in Figure 2, NUTS-3 regions where the change in the number of active insured employees varies between 0 and -1 percent due to the COVID-19 measures are not concentrated in a particular location in Turkey. The employment rate increased in Aksaray, Mardin, and Muğla, which are 
NUTS-3 regions where employment decreased between 0 and 1 percent from December 2019 to March 2020, when the first official case of COVID-19 was reported in Turkey. This suggests that the pandemic measures increased unemployment in Aksaray, Mardin, and Muğla from March to May 2020 (see table 3).

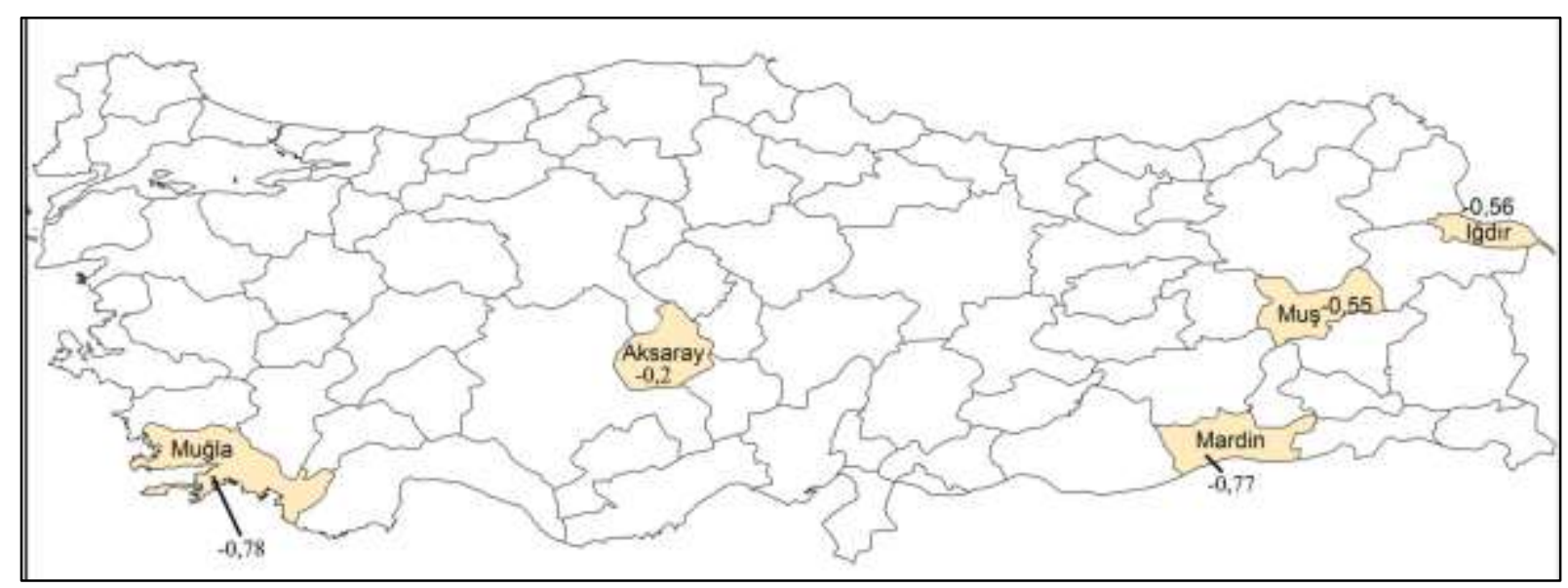

Figure 2. NUTS-3 regions with 0 to 1 percent decrease in the number of active insured employees (December 2019-May 2020)

As shown in Figure 3, NUTS-3 regions where the number of active insured employees decreased by 1 to 2 percent from December 2019 to May 2020 due to the effect of the COVID-19 pandemic are Nevşehir, Balıkesir, Gaziantep, Bingöl, Sinop, Kocaeli, Kastamonu, Tekirdağ, Çanakkale, Çankırı, and Diyarbakır. Aside Diyarbakır, the number of employment in these metropolitan cities increased until the pandemic measures, including curfews and reduced mobility, were implemented; however, the number of employment rapidly decreased after the measures were implemented. There was an increase in employment in Nevşehir, Balıkesir, Gaziantep, Kocaeli, Tekirdağ, and Çanakkale up to March 2020, when the pandemic measures were implemented (see table 3).

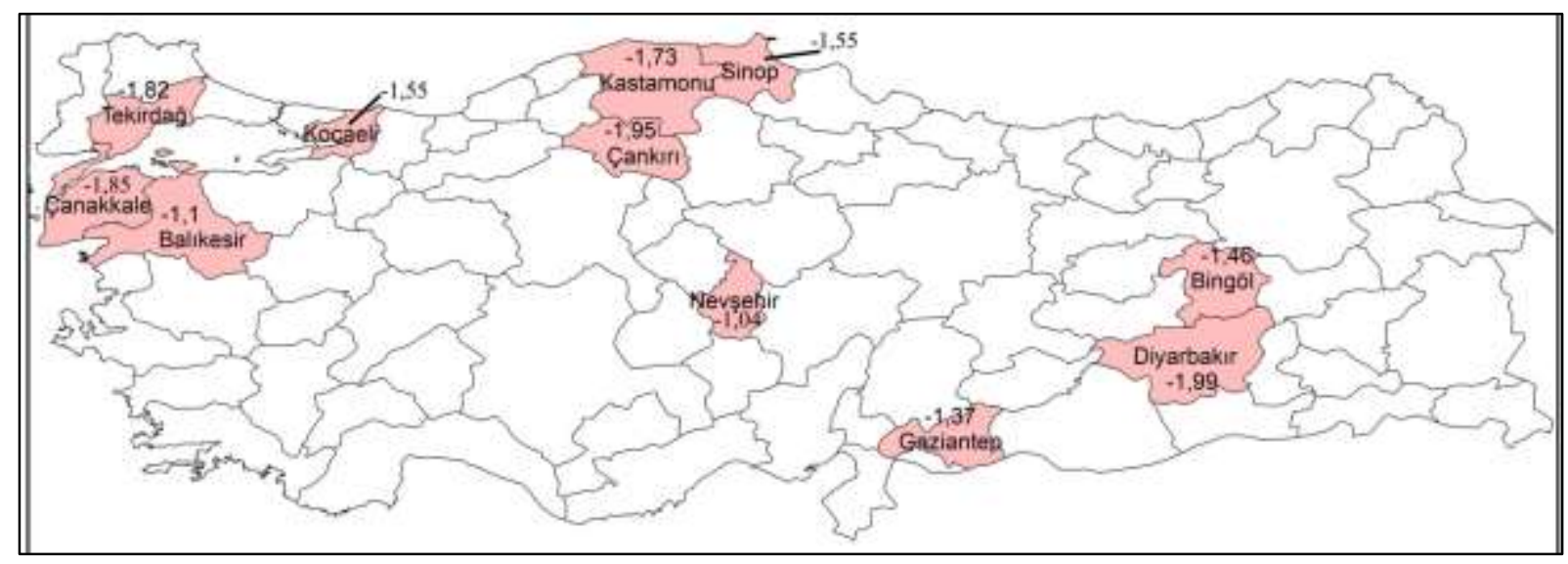

Figure 3. NUTS-3 regions with a 1 to 2 percent decrease in the number of active insured employees (December 2019-May 2020) 
As shown in Figure 4, NUTS-3 regions where the number of active insured employees decreased by 2 to 3 percent. These regions are Karaman, Hakkari, Hatay, Tokat, Artvin, Adıyaman, Şanlıurfa, Malatya, Ordu, Kahramanmaraş, Van, Zonguldak, Mersin, Osmaniye, Kırıkkale, Yozgat, Edirne, and Kütahya. There was an increase in employment in Hatay, Zonguldak, and Edirne from December 2019 to March 2020, but unemployment increased from March to May 2020 (see table 3). Although Zonguldak is not a metropolitan municipality, it is the only city where the weekend curfews imposed on metropolitan cities were also imposed. This may be the reason for the decrease in the number of active insured employees in Zonguldak during this period. Although from December 2019 to March 2020, the number of employment only increased in Hatay, among the metropolitan cities shown in gray in Table 3 , unemployment increased in other metropolitan cities.

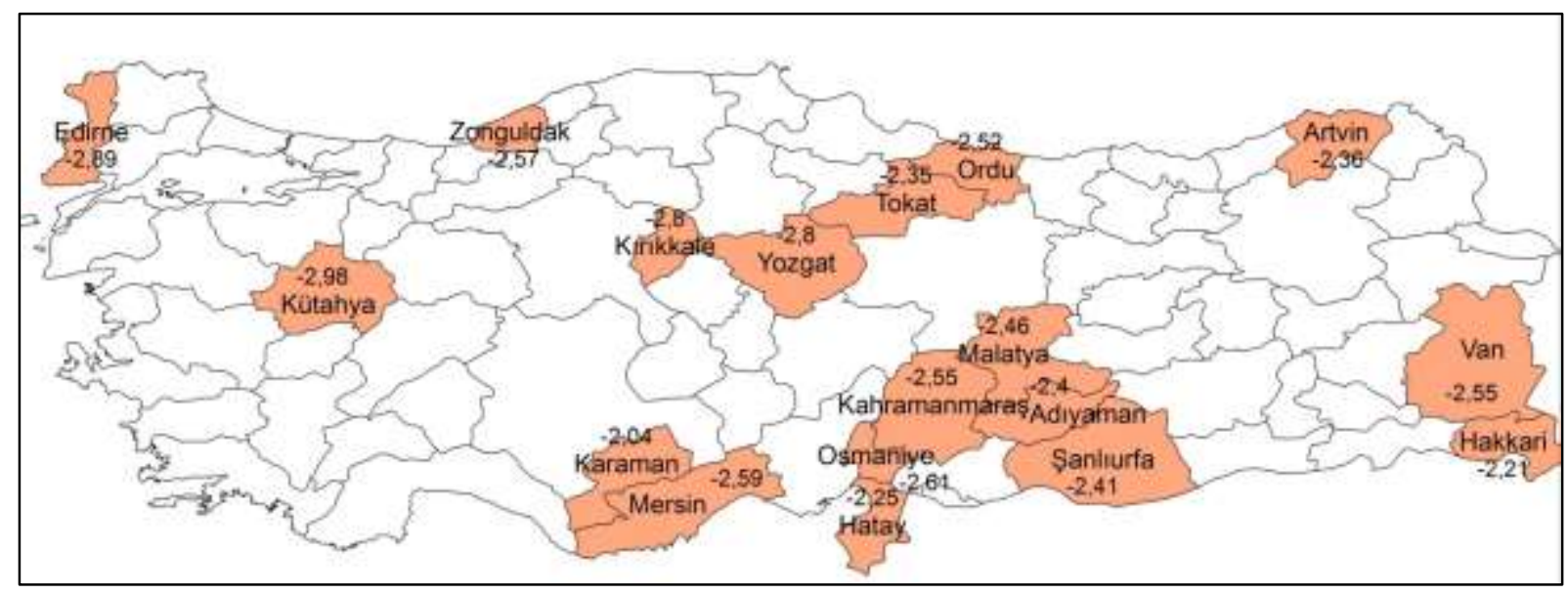

Figure 4. NUTS-3 regions with a 2 to 3 percent decrease in the number of active insured employees (December 2019-May 2020)

Figure 5 shows NUTS-3 regions where the number of active insured employees decreased by 3 to 4 percent from December 2019 to May 2020. Among these regions, employment increased in Düzce, Kırşehir, Aydın, and İzmir from December 2019 to March 2020 (see table 3). From March to May, the measures taken to prevent the spread of COVID-19 significantly decreased employment in these regions. 


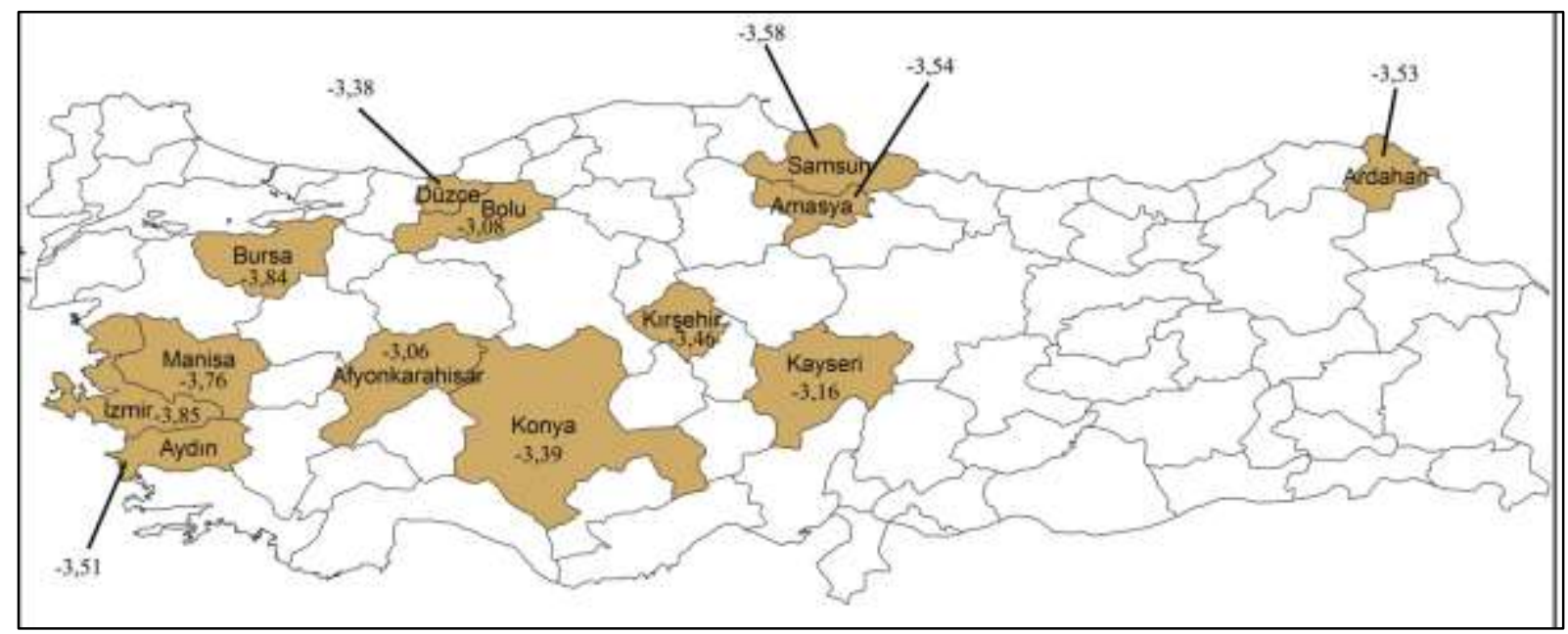

Figure 5. NUTS-3 regions with a 3 to 4 percent decrease in the number of active insured employees (December 2019-May 2020)

As depicted in Figure 6, NUTS-3 regions where unemployment increased by 4 to 5 percent from December 2019 to May 2020. Bartın, Sakarya, Bursa, and Giresun are NUTS-3 regions where unemployment decreased from when the first official case of COVID-19 was detected in the world and when COVID-19 measures were implemented in Turkey. Sakarya, Antalya, Denizli, Adana, and Trabzon, which are NUTS-3 regions shown in gray in Table 3, are metropolitan municipalities.

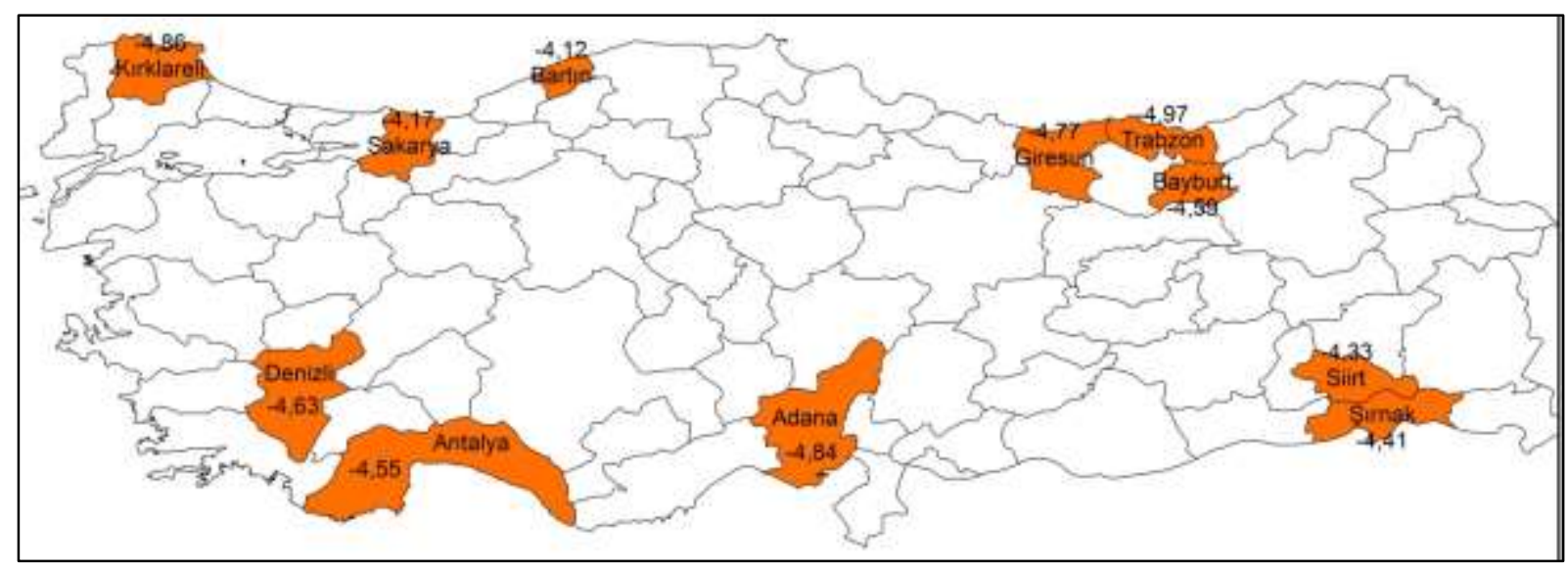

Figure 6. NUTS-3 regions with a 4 to 5 percent decrease in the number of active insured employees (December 2019-May 2020)

Figure 7 shows NUTS-3 regions where the number of active insured employees decreased by more than 5 percent. Istanbul, Eskişehir, and Ankara, which are shown in gray in the table 3, are metropolitan municipalities. Istanbul and Ankara have the highest number of employment in Turkey, so they experienced the highest loss of employment during the pandemic (see Table-3. Burdur is the NUTS-3 region where the number of active insured employees decreased the most from December 2019 to May 2020, with a rate of $10.44 \%$. There was an increase in employment in Yalova and Istanbul until March 
2020, but unemployment rapidly increased in these regions due to the implementation of the COVID-19 pandemic measures.

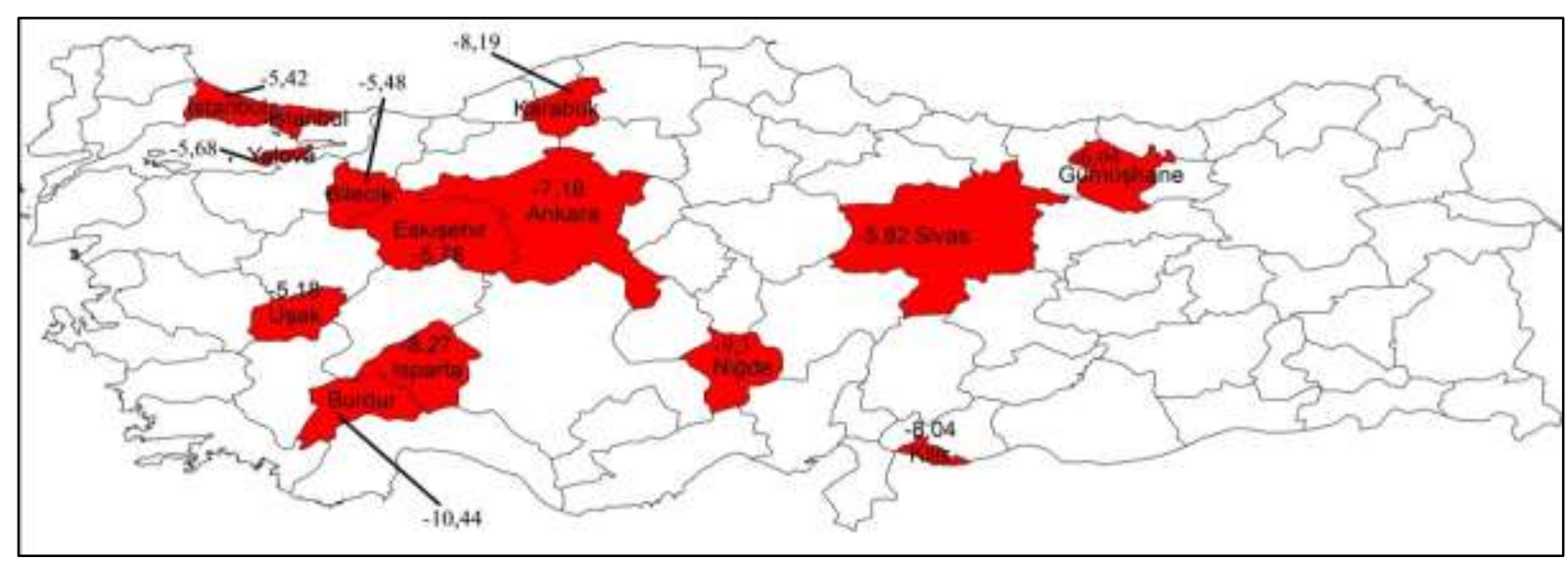

Figure 7. NUTS-3 regions with more than 5 percent decrease in the number of insured employees (December 2019-May 2020)

Table 4 shows the changes in the number of active insured employees in Turkey from December 2019 to May 2020. According to the SSI data, the total number of active insured employees was 16,010,002 in December 2019 and 16,019,026 in March 2020, indicating an increase in employment by approximately 9,000. As a result of the measures implemented to prevent the spread of COVID-19 in March, April, and May 2020, such as the prohibition of travel between provinces, "stay at home" calls, and weekend curfews in metropolitan cities and Zonguldak, the number of active insured employees decreased to 15,361,609 at the end of May 2020. The total job loss from May 2020 to December 2019 is 648,393. From March 2020 to the end of May 2020, due to the measures implemented to reduce the spread of COVID$19,657,417$ lost their jobs. Therefore, the pandemic measures had a negative impact on employment.

Table 4. Changes in the number of insured employees in Turkey (December 2019 - March 2020 - May 2020)

\begin{tabular}{|c|c|c|c|c|c|c|}
\hline $\begin{array}{l}\text { Number of } \\
\text { Employees }\end{array}$ & $\begin{array}{l}\text { Number of } \\
\text { Employees }\end{array}$ & $\begin{array}{c}\text { Number of } \\
\text { Employees May }\end{array}$ & $\begin{array}{c}\text { Difference } \\
\text { between }\end{array}$ & $\begin{array}{c}\text { Difference } \\
\text { between May }\end{array}$ & $\begin{array}{c}\text { Difference } \\
\text { between }\end{array}$ & $\begin{array}{c}\text { Increase in } \\
\text { unemployment }\end{array}$ \\
\hline December 2019 & March 2020 & 2020 & $\begin{array}{c}\text { May } 2020 \text { - } \\
\text { December } \\
2019\end{array}$ & $\begin{array}{c}2020-\text { March } \\
2020\end{array}$ & $\begin{array}{c}\text { March } 2020 \\
\text { - December } \\
2019\end{array}$ & $\begin{array}{c}\text { in two months } \\
(\%)\end{array}$ \\
\hline $16,010,002$ & $16,019,026$ & $15,361,609$ & $\begin{array}{l}-648,393 \\
\end{array}$ & $-657,417$ & 9,024 & 4.10 \\
\hline
\end{tabular}

The SSI's data for June, when the normalization measures started to be implemented and movement restrictions and bans were lifted, were examined to determine whether the data in Table 4 were affected by the COVID-19 pandemic. In June 2020, 15,890,858 employees were insured in Turkey. Moreover, with the removal of the pandemic measures, compared with that of May 2020, the number of active insured employees increased by 529,249 in June 2020.

The top ten NUTS-3 regions with the highest unemployment from December 2019 to May 2020 are all metropolitan cities. As shown in Table 5, the NUTS-3 region where the number of active insured employees decreased the most up to March 2020 is Adana, where a total of 8,448 were unemployed. As 
shown in Table 3, there was an increase in employment in some NUTS-3 regions, but unemployment gradually increased after the first case of COVID-19 was reported in Turkey and the pandemic measures were implemented.

Table 5. NUTS-3 regions with the highest increase in unemployment (Top 10 NUTS-3 regions)

\begin{tabular}{lccc}
\hline NUTS-3 Regions & $\begin{array}{c}\text { Difference in the Number of } \\
\text { Insured Employees between } \\
\text { December 2019 and March 2020 }\end{array}$ & $\begin{array}{c}\text { Difference in the Number of } \\
\text { Insured Employees between } \\
\text { March 2020 and May 2020 }\end{array}$ & $\begin{array}{c}\text { Total Unemployment } \\
\text { December 2019 to May 2020 }\end{array}$ \\
\hline Adana & $-8,448$ & $-8,431$ & $-16,879$ \\
& $(-2,42 \%)$ & $(-2,47)$ & $(-4,84 \%)$ \\
\hline Ankara & $-5,125$ & $-94,432$ & $-99,557$ \\
& $(-0,36 \%)$ & $(-6,83 \%)$ & $(-7,18 \%)$ \\
\hline Antalya & 10,292 & $-34,831$ & $-24,539$ \\
& $(1,9 \%)$ & $(-6,33 \%)$ & $(-4.55 \%)$ \\
\hline Bursa & $-3,829$ & $-24,577$ & $-28,406$ \\
& $(-0,51 \%)$ & $(-3,33 \%)$ & $(-3.84 \%)$ \\
\hline Denizli & $-1,733$ & $-8,169$ & $-9,902$ \\
& $(-0,81 \%)$ & $(-3,85 \%)$ & $(-4.63 \%)$ \\
\hline Eskişehir & $-2,044$ & $-8,676$ & $-10,720$ \\
& $(-1,10 \%)$ & $(-4,72 \%)$ & $(-5.78 \%)$ \\
\hline İstanbul & 29,143 & $-268,913$ & $-239,770$ \\
& $(0,65 \%)$ & $(-6,03 \%)$ & $(-5.42 \%)$ \\
\hline İmir & 164 & $-37,370$ & $-37,206$ \\
& $(0,016 \%)$ & $(-3,86 \%)$ & $(-3.85 \%)$ \\
\hline Konya & $-3,283$ & $-8,544$ & $-11,827$ \\
& $(-0,94 \%)$ & $(-2,47 \%)$ & $(-3.39 \%)$ \\
\hline Manisa & -39 & $-10,187$ & $-10,226$ \\
& $(-0,014)$ & $(-3,74 \%)$ & $(-3.76 \%)$ \\
\hline Total & $\mathbf{1 5 , 0 9 8}$ & $-504,130$ & $-489,032$ \\
\hline
\end{tabular}

The number of active insured employees decreased by 648,393 from December 2019 to May 2020. It is noteworthy that out of the 648,393 people, 489,032 are from the metropolitan NUTS-3 regions specified in Table 5. The pandemic measures implemented in metropolitan municipalities at weekends contributed to the decrease in employment. Figure 8 shows NUTS-3 regions where the employment increased up to March 2020 but decreased after March 2020 due to the pandemic measures implemented. 


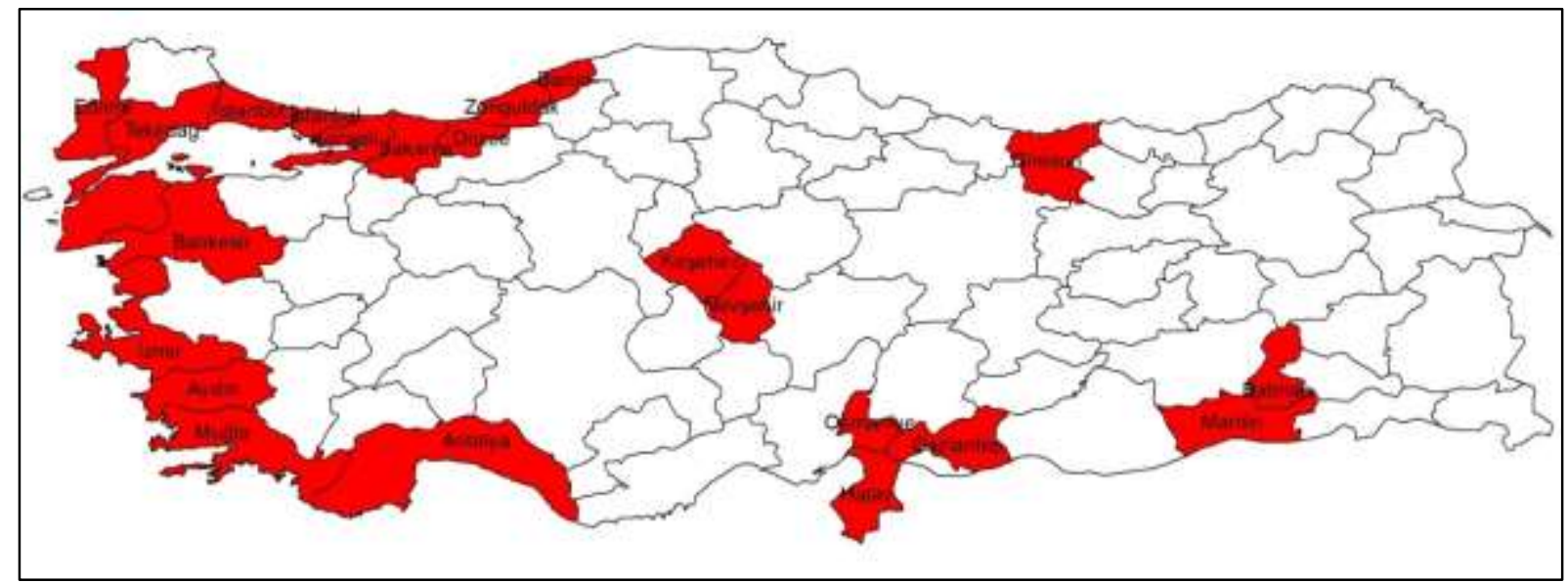

Figure 8. NUTS-3 regions where employment rate increased up to March 2020

\section{Discussion and Conclusion}

People like to stay in cities due to their dynamic structures as well as economic, occupational, social, and cultural opportunities. The urban economy has been effective in capital accumulation and population growth in cities since the industrial revolution. Negative interruptions in this dynamic structure, curfews, and restrictions on social and cultural opportunities cause serious economic problems in cities. This study examined the short-term effects of the COVID-19 pandemic on unemployment in NUTS-3 regions of Turkey. The result shows that unemployment decreased by 9,024 from December 2019, when the first official case of COVID-19 was announced in the world, to March 2020, when the first official case of COVID-19 was reported in Turkey. But according to the SSI's data on the number of active insured employees, the measures taken after the first official case of COVID-19 was reported in Turkey made 657,417 people lose their jobs in a short time. The top ten NUTS-3 regions with an increase in unemployment from December 2019 to March 2020 are metropolitan cities. The COVID-19 measures were tighter in metropolitan municipalities than in other NUTS-3 regions. A total of 504,130 people were unemployed in these ten metropolitan cities from March to May 2020. Although, in Turkey, dismissal of employees was prohibited during the pandemic, the COVID-19 pandemic increased total unemployment by 4.10 percent in a short period. Before the COVID-19 measures were implemented, Adana had the most dismissal of employees, with 8,448 dismissals. Beside Adana had the most dismissal of employees percent $(-2,42 \%)$, before the COVID-19 measures were implemented. The impact of the COVID-19 measures has been more devastating. As a result of the COVID-19 measures, Istanbul had the most unemployment from March to May 2020, where a total of 268,913 people were unemployed. Ankara had second dismissal of employees, and İzmir had the third dismissal of employees, after the COVID-19 measures were implemented. However Ankara had the most dismissal of percentage $(-6,83 \%)$, Antalya had the second dismissal of percentage $(-6,33 \%)$ and İstanbul is the third dismissal of percentage $(-6,03 \%)$, after the COVID-19 measures were implemented. Cities have been transformed due to external influences, and their dynamic structures have deteriorated due to "stay at home" calls and curfews, affecting urban economies negatively. The "transition to normalization" process should be managed well to sustain the urban economy and reduce unemployment. Since the effects of the pandemic measures on urban economies were not considered, much greater unemployment will be experienced in cities. A 
significant conclusion of this study is that urban economies cannot sustain this process any longer. The measures implemented to manage the COVID-19 pandemic increase unemployment. Increased unemployment, employment without insurance, changes in sectorial structures, deteriorations in employee wages, the impact of the pandemic measures, and technological changes are expected to emerge in cities in the future, so future studies should discuss these issues.

\section{Ethics Committee Permission}

This article is not part of a working group that requires ethical committee approval.

\section{Acknowledgment}

I thank the Editor and two anonymous reviewers for their comments, which significantly improved the article.

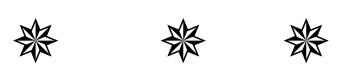




\section{Kaynakça}

Babones, S. J. (2007). Studying globalization: Methodological issues. In George Ritzer (Ed.). The blackwell companion to globalization (pp.144-161). Oxford: Blackwell.

Batty, M. (2020). The coronavirus crisis: What will the post-pandemic city look like? Environ. Plan. B. Urban Analytics and City Science, 47(4), 547-552.

Beirne, K., Doorley, K., Regan, M., Roantree, B., \& Tuda, D. (2020). The potential costs and distributional effect of Covid-19 related unemployment in Ireland. Budget Perspectives, No. 2021/1, The Economic and Social Research Institute (ESRI).

Bonaccorsi, G., Pierri, F., Cinelli, M., Flori, A., Galeazzi, A., Porcelli, F., Schmidt, A. L., Valensise, C. M., Scala, A., \& Quattrociocchi, W. (2020). Economic and social consequences of human mobility restrictions under COVID-19. Proc Natl Acad Sci USA, 117, 15530-15535.

Friedmann J., \& Wolff, G. (1982). World city formation: An agenda for research and action. International Journal of Urban and Regional Research, 6(3), 309-344.

Göze Kaya, D. (2020). Koronavirüs pandemisinin küresel ekonomideki izleri: Kamu finansman dengesi, ticaret hacmi, enflasyon, işsizlik ve ekonomik büyüme. Avrasya Sosyal ve Ekonomi Araştırmalar Dergisi (ASEAD), 7(5), 221-237.

Güzey, Ö. (2012). Türkiye'de kentsel dönüşüm uygulamaları: Neo-Liberal kent politikaları, yeni kentsel aktörler ve gecekondu alanları. IDEALKENT, 3(7), 64-83.

Jacobs, J. (1969). The economy of cities. Vintage Books.

Kalu, E. N., \& Ogbonnaya, O. E. (2019). Globalization and economic nationalism: Engaging the perspectives. Journal of Arts and Management, 4(2), 63-73.

Miyao, T. (1981). Dynamic analysis of the urban economy. Academic Press.

Öktem, B. (2006). Neoliberal küreselleșmenin kentlerde inșası: AKP'nin küresel kent söylemi ve İstanbul'un kentsel dönüșüm projeleri, Planlama, 36(2), 53-64.

Öktem, B. (2011). İstanbul'da neoliberal kentleşme modelinin sosyo-mekansal izdüşümleri. Siyasal Bilgiler Fakültesi Dergisi, 44, 23-40.

Polèse, M. (2013, Winter). Five principles of urban economics: Things we know and things we don't. City Journal, http://www.city-journal.org/2013/23_1_urban-economics.html.

Polèse, M. (2005). Cities and national economic growth: A reappraisal. Urban Studies, 42(8), 1429-1451.

Sassen, S. (1991). The global city: New York, London, Tokyo. Princeton University Press.

Sassen, S. (1994). Cities in a world economy. Fine Forge Press.

Schneider, G. (2007). War in the era of economic globalization. In G. Ritzer (Ed.). The blackwell companion | 1130 | to globalization (pp. 630-643). Blackwell.

Social Security Institution [SSI]. (2020, August 31). Monthly Insured Statistics Bulletin. http://www.sgk.gov.tr/wps/portal/sgk/tr/kurumsal/istatistik/aylik_istatistik_bilgileri

Suarez-Villa, L. (1988). Metropolitan evolution, sectoral economic change, and the city size distribution. Urban Studies, 25, 1-20. 
Tekeli, İ. (2020). Salgınlar ve kentler sarmalında dünyanın geldiği nokta: COVID-19. İçinde Ö. F. Çolak (Ed.). Salgin Ekonomisi (ss. 53-88). Efil Yayınları.

淡济 